\title{
EVALUATION OF PLATELET ACTIVATION PARAMETERS AS QUALITY MARKERS FOR THE STORED PLATELETS
}

\author{
PROCENA PARAMETARA TROMBOCITNE AKTIVACIJE KAO KVALITATIVNIH \\ MARKERA ZA SKLADIŠTENE TROMBOCITE
}

\author{
Vesna Subota1, Dušan Vučetić2, Bela Balint², Zoran Mijušković1, Danilo Vojvodić3, \\ Janko Pejović, Slavka Mandić-Radić4 \\ IInstitute of Medical Biochemistry, Military Medical Academy, Belgrade, Serbia \\ Institute of Transfusion, Military Medical Academy, Belgrade, Serbia \\ 3 Institute for Medical Research, Military Medical Academy, Belgrade, Serbia \\ 4Institute for Health Care of Employees in the Ministry of Internal Affairs, Belgrade, Serbia
}

\begin{abstract}
Summary: In order to investigate the potential use of platelets activation parameters as routine quality control indicators during liquid storage, $27 \mathrm{PC}-\mathrm{BC}$ units were kept at $22{ }^{\circ} \mathrm{C}$ for up to 5 days. Routine parameters, including a platelet count, mean platelet volume and the parameters of activity: mean platelet component concentration, platelet component distribution width, mean platelet mass, platelet mass distribution width and number of platelet clumps were measured on the Bayer ADVIA 120 hematology analyzer. The platelet surface antigen $\mathrm{CD} 62 \mathrm{P}$ was investigated using monoclonal antibodies on the flow cytometer Coulter-Epics $\mathrm{XL}$ and the platelet factor 4 and $\beta$-thromboglobuline, the main components of the $\alpha$-granules, were also measured. The reduction in MPV, MPC, PCDW and MPM and the simultaneous increase in PF4, $\beta$-TG and CD62P expression reflected the PLT degranulation and activation. Minimizing cell damage during collection and storage is imperative for obtaining the PLT adequate in number and viability.
\end{abstract}

Keywords: platelets, platelet activity, platelet function, stored platelets, platelet viability
Kratak sadržaj: U cilju ispitivanja mogućnosti upotrebe aktivacionih parametara trombocita kao indikatora i markera njihovog kvaliteta, ispitali smo 27 jedinica koncentrovanih trombocita izdvojenih procesiranjem iz jedinica cele krvi, »buffy coat-a« (KC-BC), skladištenih 5 dana na temperaturi $20 \pm 2{ }^{\circ} \mathrm{C}$. Ispitivani su rutinski parametri, koji uključuju ukupni broj trombocita i srednji volumen trombocita, kao i parametri aktivacije trombocita: srednja koncentracija komponenti trombocita, distribucija širine komponenti trombocita, srednja masa trombocita, distribucija širine mase trombocita i broj trombocitnih klampova, na Bayer ADVIA 120 hematološkom analizatoru. Trombocitni površinski antigen CD62P ispitivan je anti-CD62P monoklonskim antitelom na »flow" citometru Coulter-Epics $X L$, a takođe su ispitani PF4 i $\beta$-TG kao glavne sekretorne komponente $\alpha$-granula. Redukcija u MPV, MPC, PCDW i MPM, uz simultano povećanje koncentracije PF4, $\beta$-TG i ekspresije CD62P, ukazuje na degranulaciju i aktivaciju trombocita. To ukazuje na neophodnost minimiziranja ćelijskog oštećenja tokom sakupljanja i skladištenja uzoraka kao na imperativ za dobijanje trombocita adekvatnog broja i vijabilnosti.

Ključne reči: trombociti, aktivacija trombocita, funkcija trombocita, skladišteni trombociti, vijabilnost trombocita

\section{Introduction}

Platelets play a key role in primary haemostasis and therefore are a target of major interest in the investigation. Since platelets were first identified in the 1870s, there has been a continuous and recently accelerating progress in our basic understanding of the platelet function. Despite this great progress and the fact that platelets are so readily accessible for

\footnotetext{
Address for correspondence:

Vesna Subota

Institute of Medical Biochemistry

Military Medical Academy

Crnotravska 17, 11000 Belgrade

Tel.: 063/73 98712

e-mail: vsubota@ptt.yu
} 
study compared with non-circulating human cells, there is a remarkable paucity of clinically useful tests of platelet function. Tests of platelet function have included measurements of the ability of platelets to adhere, aggregate, and/or activate.

It has become a standard practice to assess the viability of platelets concentrates (PC) after storage for transfusion (1). In this paper we report outstanding results in such an experiment, using platelets stored for 5 days.

Murphy and Gardner (2) studied storage of platelet-rich plasma (PRP) obtained from whole blood donations to show that in vivo recovery and survival of platelets were best preserved at $22{ }^{\circ} \mathrm{C}$, rather than at $4{ }^{\circ} \mathrm{C}$. They suggested losing of platelets viability and resembled platelet life span in vivo (3).

Both platelet morphology and function may be affected by processing and storage and they may thus be less effective when transfused than fresh platelets. To be effectively transfused, platelets must be adequate both in number and viability. A wide size range, rapid shape changes and a tendency of the platelets to clamp in vitro make platelet counting less reliable compared to other blood cells. There are several methods for quality control of platelet components including platelet counting, but the latter includes morphology, extent of the shape change and markers for platelet activation $(4,5)$. Traditional cell counters, which use impedance, contribute to this relatively poor result, especially in the thrombocytemic or thrombocytopenic range. Murphy (6), however, suggested that a reevaluation using newer counters was needed because simultaneously measuring the volume and density of platelets on a cell-by-cell basis using two angles of laser light scatter, provides not only a more accurate platelet count, but also new parameters including the mean platelet component concentration (MPC), platelet component distribution width (PCDW), mean platelet mass (MPM) and platelet mass distribution width (PMDW) as indicators of platelets activity $(7,8)$.

Activation of thrombocytes is followed by an increased expression of P-selectin (CD62P) on the thrombocyte membrane, which correlates with the level of thrombocyte activation and is an indirect marker of their activation $(9,10)$. The values of this protein, as well as of the platelet factor 4 (PF4) and $\beta$-thromboglobuline ( $\beta-\mathrm{TG})$, the main components of the $\alpha$-granules secreted from the granules during the release reaction induced by $A D P$, epinephrine, collagen and thrombin, almost doubled after the storage $(11,12)$.

The aim of this study was to characterize the quality of platelet activation parameters changes during liquid storage at $20 \pm 2{ }^{\circ} \mathrm{C}$ of platelet concentrates derived from a buffy-coat (PC-BC) by evaluation of its morphological and functional changes and to investigate the possibility of its use as a routine quality control indicator in the preparation and storage of platelet components.

\section{Patients and Methods}

Testing included 27 PC-BC samples, prepared from blood units taken from randomly selected volunteers (aged from 18 to 65) who had not taken preparations containing acetylsalicylic acid (during last 7 days). The samples were adequately stored at the temperature of $22 \pm 2{ }^{\circ} \mathrm{C}$ for up to 5 days, including constant stirring, and platelet parameters were measured on day 1 (control group, group 1), 3 (group 2) and 5 (group 3).

Blood samples from volunteers for testing concentrations of a CD62P, PF4 and $\beta$-TG were collected from the vein of the opposite arm in view of the arm from which the donor's blood is normally taken, without using a ligature and using a needle the diameter of which was 19-20 gauge. Commercial test tubes with Na-citrate (Venoject ${ }^{\circledR}$ II Terumo) were used. Sample preparation was made so that the platelet poor plasma (PPP) was separated from the test tube by centrifuging at $1000 \mathrm{~g}$ during $10 \mathrm{~min}$ at $4{ }^{\circ} \mathrm{C}$, i.e. from the $\mathrm{PCBC}$ samples into a plastic test tube. These samples were stored until being tested by the quantitative enzymoimmune test (Human sP-selectin ELISA, Bender MedSystems ${ }^{\top \mathrm{M}}$ Diagnostics $\mathrm{GmbH}$, Vienna, Austria) and values were expressed in $\mu \mathrm{g} / \mathrm{L}$. Detection of PF4 and $\beta$-TG was performed by an antibody-based PF4 Behring ELISA kit, according to the manufacturer's instructions and PF4 and $\beta$-TG were measured by the Beckman Du- 8 spectrophotometer. Platelet morphological parameters were determined using the haematology system ADVIA 120, the platelet surface antigen CD62P using a flow cytometer Coulter-Epics XL. For comparison of results, a paired t-test was used. All results were given as the mean ones \pm SD. A P level of $<0.05$ was considered significant.

\section{Results}

As it is shown in Table I, by comparing the number of thrombocytes, stored at ambient temperature $\left(20 \pm 2{ }^{\circ} \mathrm{C}\right)$ in the course of five days, there was no statistically relevant decline in the samples from group 2 (420.8 $\pm 230.3, \mathrm{p}>0.05)$, nor from group $3(410.7 \pm 222.0, p>0.05)$ in relation to the average values in the control group $(471.4 \pm 273.9)$.

There were significant changes in MPC, PCDW and PMDW. By comparing MPC ( $\mathrm{g} / \mathrm{L})$, a statistically relevant decline of concentration was found in the thrombocyte samples from the groups 2 (201.9 \pm 9.37, $\mathrm{p}<0.05)$ and $3(197.1 \pm 9.2 \mathrm{p}<0.05)$ in relation to the average values in the control group (216.4 \pm 11.6). PCDW $(\mathrm{g} / \mathrm{L})$ gradually decreased from 
$70.0 \pm 9.6$ in the control group to $56.6 \pm 6.1$ in group 3, and PMDW and clamps showed significant increase from $0.63 \pm 0.06$ to $0.81 \pm 0.07$ and from $37 \pm 21$ to $41 \pm 20$ respectively.

By comparing the concentrations of a CD $62 \mathrm{P}(\%)$ between the thrombocytes stored at ambient temperature in the course of five days, a statistically relevant increase of the concentration of P-selectin in the thrombocyte samples was found in the groups 2 (31.000 $\pm 11.958, \mathrm{p}<0.05)$, and group 3 (52.714 $\pm 28.546, \mathrm{p}<0.05)$, in relation to the average values in the control group (29.428 \pm 6.604$)$.

There was no statistically relevant increase in the concentration of PF4 $(\mu \mathrm{g} / \mathrm{L})$ in the samples of the same donor after the day 3 (group 2) (438.3 \pm 244.0, $\mathrm{p}<0.05$ ), but there was a statistically relevant increase in the concentration of PF4 after the day 5 (group 3) $(1385.0 \pm 383.1, \mathrm{p}<0.05)$ in relation to the average values in the control group (group 1) (128.1 \pm 34.8). $\beta$-TG $(\mathrm{IU} / \mathrm{mL})$ shows a statistically relevant increase of concentration in the thrombocyte samples from the same donor after the day 3 (760.0 $\pm 294.7, \mathrm{p}<0.05)$ and after the day 5 (1345.8 \pm

Table I The mean values \pm SD of platelet (PLT) parameters on ADVIA 120 according to the storage time.

\begin{tabular}{|l|c|c|c|}
\hline Group & 1 & 2 & 3 \\
\hline PLT $\left(\times 10^{9} / \mathrm{L}\right)$ & $471.4 \pm 273.9$ & $420.8 \pm 230.3$ & $410.7 \pm 222.0$ \\
\hline MPV (fL) & $9.0 \pm 0.63$ & $8.68 \pm 0.79$ & $8.75 \pm 0.67$ \\
\hline PDW (\%) & $49.9 \pm 5.05$ & $50.7 \pm 6.0$ & $50.2 \pm 5.06$ \\
\hline PCT (\%) & $1.7 \pm 0.12$ & $1.6 \pm 0.13$ & $1.6 \pm 1.09$ \\
\hline MPC (g/L) & $216.4 \pm 11.6$ & $201.9 \pm 9.37^{*}$ & $197.1 \pm 9.2^{*}$ \\
\hline PCDW (g/L) & $70.0 \pm 9.6$ & $85.9 \pm 11.9^{*}$ & $56.6 \pm 6.1^{*}$ \\
\hline MPM (pg) & $1.7 \pm 0.12$ & $1.6 \pm 0.13$ & $1.6 \pm 1.09$ \\
\hline PMDW (pg) & $0.63 \pm 0.06$ & $0.62 \pm 0.07$ & $0.81 \pm 0.07^{*}$ \\
\hline $\begin{array}{l}\text { Plt clumps } \\
\text { (Number of clumps) }\end{array}$ & $37 \pm 21$ & $39 \pm 21$ & $41 \pm 20^{*}$ \\
\hline
\end{tabular}

* $\mathrm{p}<0.05$

Group 1: Platelets obtained $24 \mathrm{~h}$ after blood collection

Group 2: Platelets obtained 3 days after blood collection

Group 3: Platelets obtained 5 days after blood collection

Table II The mean values for platelet $\alpha$-granules parameters and CD62P expression during storage time.

\begin{tabular}{|l|c|c|c|}
\hline Group & 1 & 2 & 3 \\
\hline PF4 $(\mu \mathrm{g} / \mathrm{L})$ & $128.2 \pm 34.8$ & $438.4 \pm 244.0$ & $1385 \pm 383^{*}$ \\
\hline$\beta T G(\mathrm{IU} / \mathrm{mL})$ & $151.6 \pm 81$ & $760.0 \pm 294^{*}$ & $1345 \pm 249^{*}$ \\
\hline CD62P $(\%)$ & $29.4 \pm 6.6$ & $31.0 \pm 11.9 *$ & $52.7 \pm 28.5^{*}$ \\
\hline
\end{tabular}

* $p<0.05$

Group 1: Platelets obtained $24 \mathrm{~h}$ after blood collection

Group 2: Platelets obtained 3 days after blood collection

Group 3: Platelets obtained 5 days after blood collection
$249.2, p<0.05)$ in relation to the average values in the control group - fresh thrombocytes (151.6 \pm 81.2).

\section{Discussion}

Thrombocyte transfusions in patients with thrombocytopenia can significantly reduce mortality caused by bleeding, and the therapeutic use of concentrated thrombocytes (CT) enabled the use of higher radio and chemotherapeutic doses in curing malign chemopathies and solid tumors or in the treatment of thrombocytopenic conditions, such as a dilute thrombocytopenia during an operation on the open heart (13). Production of thrombocytes has been increasing over the recent years mainly due to the reduced activation of thrombocytes, a lower number of leukocytes and a better preserved function of platelets $(14,15)$.

Platelet parameters including a platelet count, distribution width, mean platelet volume and plateletcrit can be obtained conventionally, but these parameters give no information about the activation state of platelets. We analyzed the newly introduced parameters MPC, PCDW, MPM and PMDW, which provide new insight into the activation procedure $(16,17)$.

A number of studies confirmed that storage of thrombocytes during five days does not produce a statistically significant fall in the number of thrombocytes. In our study there is a substantial decrease of approximately $11 \%$ in the group 2 , and $13 \%$ in the group 3 , when compared with the control group (group 1).

The Bayer Diagnostic developed tests for the automated flow cytometric detection of activated platelets include the MPC and PCDW. The MPC is dependant on determining a platelet refractive index, which is linearly related to platelet density, and activated platelets degranulate reducing MPC. The PCDW measures variations in platelet density and granularity. In this study there was a significant reduction in MPC and PCDW. Gradually decreased, they showed a significant difference between groups reflecting a storage time and shape change, which occurs as an early event during the platelet activation and leads to a surface receptor redistribution that can alter the role which then could acquire prothrombotic properties. The extent of the shape change has been reported to be a sensitive marker and predictor of platelet viability, even more sensitive than the platelet CD62P expression.

CD62P, and platelet $\alpha$-granule component, are known to be redistributed to the plasma membrane during the platelet activation and degranulation. Examining the P-selectin at the stored thrombocytes by means of a flow cytometry technique before transfusion provides direct evidence of its changes and the activation of thrombocytes (18). These changes cor- 
relate with the changes in the thrombocyte morphology. That is why it has been suggested by some authors that the activated (P-selectin positive) thrombocytes have a shortened period of survival and recovery after transfusion, and that measuring the Pselectin at the thrombocyte surface in $\mathrm{PCBC}$ can predict in vivo survival and/or the function (19). We determined the CD62 expression as a measure of platelet activation over time and increasing in CD62P, in accordance with the statement given by Macey (20), that MPC is inversely correlated with CD62P expression. There are technological limitations associated with the method of measuring CD62P, the fluorescence flow cytometry, and using new platelet activation parameters, which do not require a platelet activation specific receptor, may circumvent this problem. For instance, in some patients in vivo activated platelets lose their granules and receptors, continue to circulate and function, but are not detected by the fluorescence methodology. It is therefore anticipated

\section{References}

1. Bock M, Rahrig S, Kunz D, Lutze G, Heim MU. Platelet concentrates derived from buffy coat and apheresis, biochemical and functional differences. Transfusion Medicine 2002; 12: 317-24.

2. Murphy S, Gardner FH. Platelet storage at 22 degrees C; metabolic, morphologic and functional studies. The Journal of Clinical Investigation 1971; 50: 370-7.

3. Rothwell SW, Maglasang P, Reid TJ, Gorogias M, Krishnamurti $C$. Correlation of in vivo and in vitro functions of fresh and stored human platelets. Transfusion 2000; 40: 988-93.

4. Chapman ES, Lerea KM, Kirk R, Sorette MP, Sanjay NS, Zelmanovic D. Monitoring in vitro and in vivo platelet activity: comparison of alpha granule release, density distribution, platelet adhesion and mean platelet component concentration (MPC). Blood 1998; 68B, Abstract 3273.

5. Chapman ES, Sorette M, Hetherington E, et al. A rapid, automated flow cytometric method to measure activated degranulated platelets by density determination. Thromb Haemost 2003; 89: 1004-15.

6. Murphy S, Heaton WA, Rebulla P. Platelet production in the Old World and the New. Transfusion 1996; 36: 751-4.

7. Marcey MG, Carty E, Webb L, Chapman ES, Zelmanovic $D$, Okrongly $D$, et al. Use of mean platelet component to measure platelet activation on the ADVI$A^{\mathrm{TM} 120}$ Haematology system. Cytometry Commun Clin Cytometry 1999; 38: 250-5.

8. Kunicka JE, Fischer G, Murphy J, Zelmanovic D. Improved platelet counting using two-dimensional laser light scatter. American Journal of Clinical Pathology 2000; 114: $283-9$. that MPC will provide a convenient and cost-effective measure of the activation status and storage lesion of platelets for transfusion. The MPV and MPM were decreased, but not significantly, indicating changes in volume and a loss of mass and granule release, both of which occur during the platelet activation. The values of PF4 and $\beta$-TG are doubled after the fifth day of storage and indicate the platelets release.

Our data and experience of the previous study suggest that new and specific platelets activation parameters may be used by laboratories as a sensitive test to assess the viability and storage lesion of platelets. It would be helpful for the patient if explicit standards for the percentage of recovery and survival of platelets could be evolved against which future innovations could be compared as it has been done for erythrocytes. However, this research has brought, developed and confirmed improvements in the collection AND storage of thrombocytes.

9. Blann AD, Lip GYH. Hypothesis - is soluble P-selectin a new marker of platelet activation? Atherosclerosis 1997; 128: 135-8.

10. McEver RP. Regulation of function and expression of Pselectin. Agents Actions Supply 1995; 47: 117-19.

11. Ryo R, Proffitt RT, Poger ME, O Bear R, Deuel TF. Platelet factor 4 antigen in megakaryocytes. Thromb Res 1980; 17: 645-52.

12. McLaren KM, Holloway L, Pepper DS. Human platelet factor 4 and tissue mast cells. Thromb Res 1980; 19: 293-7.

13. Vaickus L, Breitmeyer JB, Schlossman R, Anderson KE. Platelet transfusion and alternatives to transfusion in patients with malignancy. Stem Cells 1995; 13: 588-96.

14. Fijnheer R, Pietersz RN, De Korte D, Gouwerok CW, Dekker WJ, Reesink HW, et al. Platelet activation during preparation of platelet concentrates: a comparison of the platelet-rich plasma and the buffy-coat methods. Transfusion 1990; 30: 634-8.

15. Pietersz RNI, Loos JA, Reesink HW. Platelet concentrates stored in plasma for 72 hours at $22 \mathrm{C}$ prepared from buffycoats of citrate-phosphate-dextrose blood collection in a quadruple-bag saline-adenine-glucosemannitol system. Vox Sang 1985; 49: 81-5.

16. Ifran $A$, et al. Evaluation of platelet parameters in healthy apheresis donors using the ADVIA TM120. Transfusion and Apheresis Science 2005; 33: 87-90.

17. Singh H, Chaudhary R, Ray V. Platelet indices as quality indicator for stored platelets. Clin Lab Haematol 2002; 25: 307-10.

18. Divers SG, Kannan K, Stewart RM, Betzing KW, Dempsey $D$, Fukuda $M$, et al. Quantitation of CD62, soluble CD62, and lysosome associated membrane proteins 1 
and 2 for evaluation of the quality of stored platelet concentrates. Transfusion 1995; 35: 292-7.

19. Rinder HM, Murphy M, Mitchell JG, Stocks J, Ault KA, Hillman RS. Progressive platelet activation with storage: evidence for shortened survival of activated platelets after transfusion. Transfusion 1991; 31: 409-14.
20. Macey M, Azam U, McCarty D, Webb L, Chapman ES, Okrongly $D$, et al. Evaluation of the Anticoagulants EDTA and Citrate, Theophylline, Adenosine, and Dipyridamole (CTAD) for Assessing Platelet Activation on the ADVIA 120. Clin Chem 2002; 48: 891-99.

Received: May 15, 2007

Accepted: July 30, 2007 